\title{
Not as Easy as E-Mail: Tutors' Perspective of an Online Assignment Submission System
}

\author{
Orit Naor-Elaiza \\ Bar-Ilan University, \\ Ramat-Gan, Israel, \\ and The Open University of Israel \\ Raanana, Israel \\ oritna@openu.ac.il
}

\author{
Nitza Geri \\ The Open University of \\ Israel \\ Raanana, Israel
}

nitzage@openu.ac.il

\begin{abstract}
Continued use of a system beyond initial adoption is one of the most challenging issues in practice and research. This study examines the continued use of an online assignment submission system, which was implemented in a blended distance learning university. The system has two main groups of users: the students who may choose between submitting their work through the system or via regular mail, and the tutors who have to check these assignments. This paper analyzes the system's continued use from the tutor's perspective. After nine years of implementation, about half of the assignments were submitted via the system. The research model, which is based mainly on the technology acceptance model (TAM) and diffusion of innovation theory, has been empirically examined with data collected via a Web survey from 89 tutors. Behavioral intention to use the system was influenced mainly by its compatibility with the assignment checking process, its perceived usefulness, its real value, and tutors' attitude toward new technologies. The findings suggest that the system is not compatible with the checking process of those tutors who are reluctant to use it.
\end{abstract}

Keywords: information systems continued use, continuance, technology acceptance model (TAM), diffusion of innovation, human computer interaction, value of information systems, instructional technologies, distance learning.

\section{Introduction}

One of the most challenging issues in information systems research is identifying the factors that affect continued use or discontinuance of a system beyond initial adoption (Bhattacherjee, 2001; Delone \& Mclean, 1992, 2003; Kim \& Malhotra, 2005; Petter, Delone, \& Mclean, 2008). Some-

Material published as part of this publication, either on-line or in print, is copyrighted by the Informing Science Institute. Permission to make digital or paper copy of part or all of these works for personal or classroom use is granted without fee provided that the copies are not made or distributed for profit or commercial advantage AND that copies 1) bear this notice in full and 2) give the full citation on the first page. It is permissible to abstract these works so long as credit is given. To copy in all other cases or to republish or to post on a server or to redistribute to lists requires specific permission and payment of a fee. Contact Publisher@InformingScience.org to request redistribution permission. times, one group of users influences the behavior of another group or the ability of its members to use the system. For example, tutors may affect their students' utilization of various instructional technologies. Homework assignments are one of the essential components of learning at all education levels, especially in higher education since some of the learning is done independently by

\section{Editor: Alex Koohang}

An earlier, shorter version of this paper was presented at the Chais conference 2009, in Raanana, Israel, and included in Y. Eshet-Alkalai, A. Caspi, S. Eden, N. Geri, \& Y. Yair (Eds.), Proceedings of the Chais conference on instructional technologies research 2009: Learning in the technological era. Raanana: The Open University of Israel. http://www.openu.ac.il/research center eng/conferences.html 
the students, and the assignments provide them with feedback. There may be sophisticated ways to support students in performing learning assignments, like the Open Assignment Submission (OAS) described by Langley, Ronen, and Ben Shachar (2008), where students post their completed assignments on an online discussion forum and their peers' feedback helps them improve their work. Nevertheless, even simple systems, such as online submission systems can be very helpful. A study of student preferences of various e-learning components revealed that their strongest preference was toward online submission of assignments and having the ability to check their assignment grades online (Buzzetto-More, 2008).

This study examines an online assignment submission system that seems similar to an e-mail system that was implemented in a blended distance learning university. Such a system is expected to be valuable mostly in a distance or blended learning environment since it expedites the process of task handling and provides students with fast feedback on their work (Chan \& Waugh, 2007; Levy, 2006). However, after seven years of implementation, the online system examined in this study handled less than $20 \%$ of the assignments. A major effort by the university management to encourage the system's use resulted in a substantial increase in the rate of adoption during the last two years. Yet, after nine years of implementation, about half of the assignments were submitted via the system.

The system has two main groups of users: the students who may choose between submitting their work through the system or via regular mail, and the tutors who have to check these assignments. This paper analyzes the system's continued use from the tutor's perspective and is a part of a comprehensive research that examined all the parties concerned with the assignments system (students, tutors, course coordinators, and the university management) and investigated the reasons for its slow adoption rate. The research model was based primarily on the technology acceptance model (TAM) (Davis, 1989; Davis, Bagozzi, \& Warshaw, 1989; Moore \& Benbasat, 1991; Venkatesh, Morris, Davis, \& Davis, 2003) and diffusion of innovation theory (Rogers, 1962, 2003). The first part of the study addressed the students through a Web survey, which was answered by over a 1,000 students who were divided into three groups: non-users, former users (those who have used the system, but apparently abandoned it), and users. The prior findings suggest that the slow adoption rate of the relatively simple system may result from insufficient support of the more complex assignment preparation and the assignment checking processes (Geri \& Naor-Elaiza, 2008; Naor-Elaiza \& Geri, 2008). These prior studies, which examined the system from the students' perspective, emphasized the crucial influence of the tutors on the continued use of the assignments system. Whereas students may be able and willing to use instructional technologies and read learning materials online (Buzzetto-More, Sweat-Guy, \& Elobaid, 2007), tutors may not be willing to engage in online activities and by doing so prevent the ability of their students to perform these activities.

Therefore, this paper focuses on the tutors. Virtually, all the tutors use the system, but in fact some of them just use it sporadically or not at all. The students may choose how to submit their assignments, and the tutors may influence their decision in various ways, including telling them explicitly not to use the system. Actually, when students who were apparently former users of the assignments system were asked why they stopped using it, the main reason they stated was unwillingness of the tutors to use it. The students said that although they would like to use the system it was not offered in the courses which they enrolled to in that semester or that either the course coordinators or the tutors do not allow using the system (Geri \& Naor-Elaiza, 2008). The tutors' attitudes toward the assignments system were first surveyed by the Evaluation Department of the Open University of Israel in June 2007 (Alberton, 2007), and the findings of that study have contributed to the research model described in the following section. The results reported in this paper are based on data collected by the authors in July 2008, from 89 course coordinators who also serve as tutors. 


\section{The Research Model and Hypotheses}

Figure 1 presents the proposed research model. The first six hypotheses are based on TAM (Davis, 1989) and information economics (Ahituv, 1989; Raban, 2007) and were supported in prior research (Venkatesh et al., 2003). According to TAM, behavioral intention is influenced by two main constructs (Davis, 1989):

Perceived Usefulness (PU) - the degree to which an individual believes that using a particular system would enhance their performance.

Perceived Ease of Use (PEOU) - the degree to which an individual believes that using a particular system would be free of physical or mental effort.

Information economics distinguishes between the real value of an information system and its perceived value (Ahituv, 1989). Real value relates to tangible benefits of an information system, such as reduced transaction costs or faster service. Perceived value concerns the perceptions of the users or the potential users of an information system and is similar to the term Perceived Usefulness (PU) of the Technology Acceptance Model. Hereafter, PU will encompass the term perceived value.

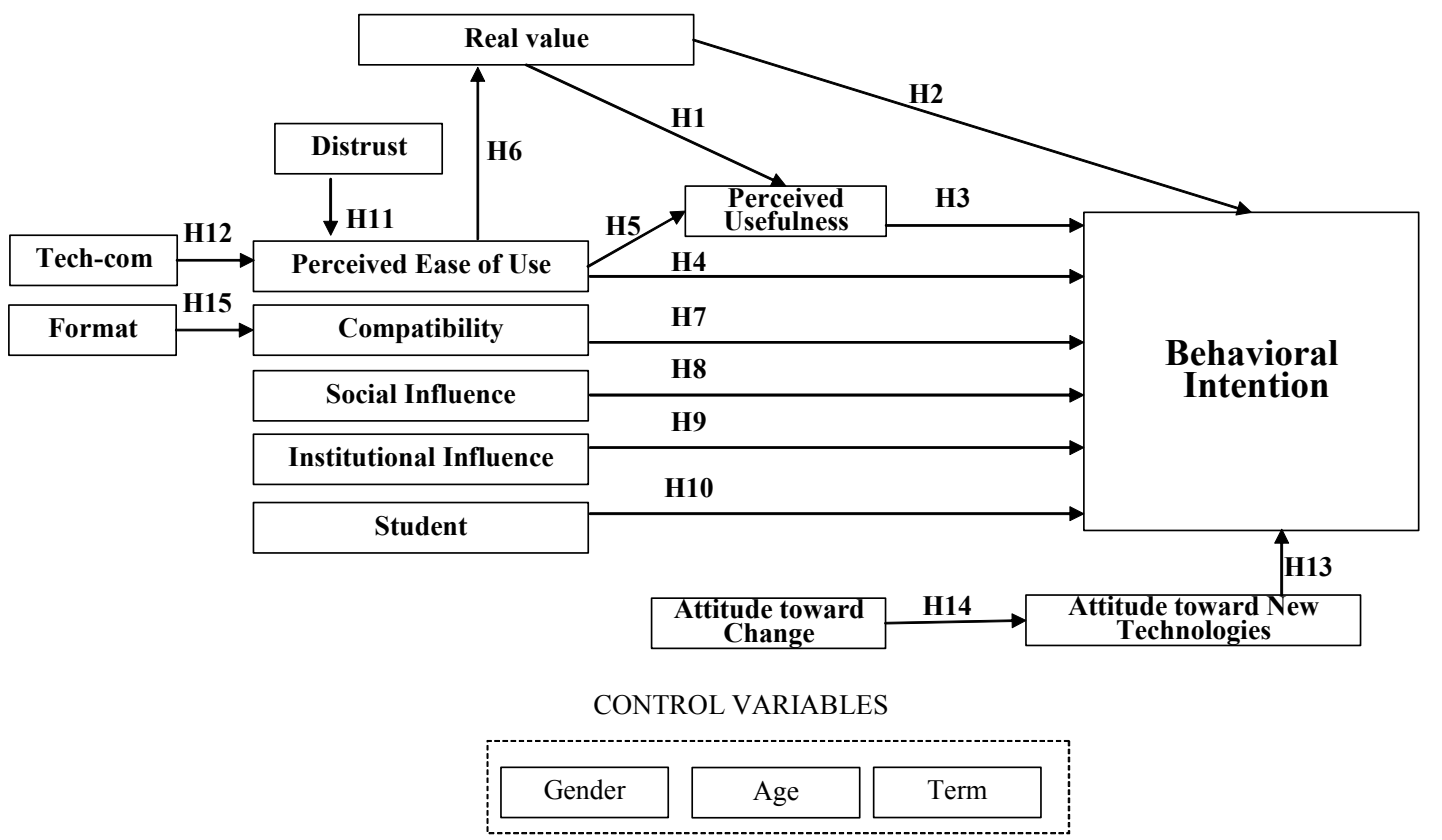

Figure 1: The Suggested Research Model

The real value of an information system is not always positively correlated with its perceived usefulness. Consider for instance a website of an academic course that enables students to view learning materials and interact with their instructors. The website saves the students time and provides them with useful information. Hence, the real value of the information system should be high. However, the response time is not satisfactory and, therefore, the impatient students prefer most of the time to call the instructors instead of using the system. Although the website provides the students with flexibility (e.g., they may post their questions and sometimes even get a response in the middle of the night), when the students are asked about the perceived usefulness of 
the system, their evaluations will be low. Nevertheless, it is expected that in most cases, real value will positively influence perceived usefulness.

H1: Real value of an information system positively influences its perceived usefulness.

It is expected that people who attribute higher real value to a certain system will be more inclined to use it.

H2: Real value enhances behavioral intention.

The following hypotheses are the main hypotheses of TAM, which were widely supported in prior research (Venkatesh et al., 2003):

H3: Perceived usefulness enhances behavioral intention.

H4: Perceived ease of use enhances behavioral intention.

H5: Perceived ease of use positively affects perceived usefulness.

Furthermore, it is expected that higher PEOU will positively influence the real value of an information system.

H6: Perceived ease of use positively influences real value.

The next nine hypotheses are suggested based on diffusion of innovation theory (Rogers, 1962, 2003), information systems adoption research (Jeyaraj, Rottman, \& Lacity, 2006), Information system continued use studies (Bhattacherjee, 2001; Bhattacherjee \& Premkumar, 2004; Gefen, 2003; Karahanna, Straub, \& Chervany, 1999; Kim \& Malhotra, 2005), as well as insights gained from the Open University Evaluation Department tutors' study (Alberton, 2007).

Compatibility is the extent to which adopting the innovation is compatible with what the potential users do (Rogers, 2003). Prior research examined different aspects of compatibility with mixed results (Karahanna, Agarwal \& Angst, 2006). In this study, compatibility refers to Rogers' (2003) definition, and examines the influence of the system's fit with tasks, on behavioral intention.

\section{H7: Compatibility positively influences behavioral intention.}

Observability is the degree to which the results of an innovation are visible to others (Barnes \& Huff, 2003). In this study, it is combined with social influence, which refers to the influence of others, such as friends and classmates, on the individual (Ajzen \& Fishbein, 1980). Venkatesh et al. (2003) found that social influence affected behavioral intention and the effect was stronger for women, for older workers, when the system use was mandatory, and when the users had limited experience. However, the construct developed by Venkatesh et al. (2003) included both peer influence and management influence. In this research, these two aspects were examined separately, while the construct social influence encompasses peer influence and observability, the construct institutional influence refers to management influence.

\section{H8: Social influence has a positive effect on behavioral intention.}

In this study, institutional influence refers to the influence of relevant organizations or institutions on the individual (Moore \& Benbasat, 1991). In the context of the assignments system analyzed here, it refers to the influence of the university management on the course coordinators and tutors, as well as its influence on the students.

\section{H9: Institutional influence positively affects behavioral intention.}

The Open University Evaluation Department tutors' study (Alberton, 2007) revealed an interesting aspect of the assignments systems value. Nearly half of the tutors who participated in the study indicated that they used the assignments system due to their students' requests. 
H10: Perceiving the system as enhancing students' utility positively influences behavioral intention.

Trust in the context of this study is defined as the extent to which the innovation adopter perceives the innovation provider to be trustworthy (Barnes \& Huff, 2003). Prior studies have found trust to influence buyer behavioral intention in commercial websites (Gefen, Karahanna, \& Straub, 2003; Pavlou \& Gefen, 2004). While a public organization or an academic institute is inherently trustworthy in the aspect of not intentionally deceiving a user, sometimes it may be very hard to correct user mistakes. Hence, trust may also represent the user belief that there are adequate procedures to handle mistakes. If the potential users are not sure they can easily correct mistakes, it will affect the PEOU of the system.

H11: Distrust negatively influences perceived ease of use.

Technical compatibility refers to the technical aspects of using a computer during the assignment checking process, such as place of work or ease of file downloading and uploading. Even experienced users, who are proficient in using computers in general (Koohang, 2004), may have difficulties handling a specific application due to some unsatisfactory features. This aspect of compatibility evolved in the pilot study of the survey.

\section{H12: Technical compatibility enhances perceived ease of use.}

People that are more inclined to use new technologies are more likely to use new information systems (Rogers, 2003).

\section{H13: Attitude toward new technologies positively affects behavioral intention.}

Those who are more adaptive to changes will tend to have a more positive attitude toward adopting new technologies (Rogers, 2003).

H14: Attitude toward change positively influences attitude toward new technologies.

Assumptions H13 and H14 have not been empirically tested in information systems contexts. Although attitude toward the specific adopted information system has been considered in prior research (Venkatesh et al., 2003), general attitude toward new technologies has not been examined in the context of technology acceptance and continued use of information systems. Both hypotheses were supported in the student surveys that were carried out in prior stages of this research (Geri \& Naor-Elaiza, 2008; Naor-Elaiza \& Geri, 2008).

Format preference refers to tutors' possible preference for reading from paper rather than a screen. Some tutors may feel that their ability to critically read assignments is enhanced when they read a printed document (Eshet-Alkalai \& Geri, 2007, 2009) or may feel uncomfortable when reading from a screen. Spencer (2006) found that learners preferred printed materials for reasons of portability, dependability, flexibility, and ergonomics. The preference for a certain format is relevant for the tutors as well as for the students.

\section{H15: Preference for paper format negatively influences compatibility.}

The model was controlled for gender, age, and term, which is the number of semesters that the tutor has been using the assignments system.

\section{Methodology}

The research model has been tested at the Open University of Israel, which is a distance-learning institute with about 45,000 students. The university offers its students the choice of a full distance-learning model or a blended learning model. Students who choose the blended model combine a few face-to-face meetings with online support through course websites to supplement tra- 
ditional means of distance education, such as books and study guides. The research reported in this paper is part of a comprehensive research that analyzed all the parties concerned with the assignments system of the Open University: students, course coordinators, tutors, and the university management.

The assignments system is a web-based system that enables the students to submit their assignment online, trace its status, and receive feedback from the tutor together with the assignment grade. The system can handle all the prevalent sorts of files (e.g., doc., xls., pdf.), and the process of submitting an assignment and grading it by the tutor can be paperless. The students' use of the system is mainly voluntary, and it offers them an alternative to sending their assignment via regular mail or handing it in person if they choose to attend a class meeting. Still, the option to use the assignments system has not been available in all the courses and it depended on the course coordinator's willingness to use the system.

The assignments system was inaugurated in February 1999 (semester 1999b) and 123 assignments were submitted through it. Seven years later, during semester 2006b, 34,500 assignments were submitted via the system, which were only $19.2 \%$ of the assignments submitted in that semester. As of 2007, the university management encourages the implementation of the system in all courses. As a first step, the course coordinators of courses with three study groups or more had to appoint at least one tutor who would check all the assignments that were submitted via the assignments system. Therefore, all the students enrolled in that course could use the system, even if they were instructed in class by another tutor who chose not to use the system. Nevertheless, the students still have the choice not to use the system. This choice is considered within the general flexibility the Open University offers its students. During semester 2008b, the assignments system handled $46 \%$ of the assignments.

The questionnaire was based mainly on items that were validated in the student surveys (Geri \& Naor-Elaiza, 2008; Naor-Elaiza \& Geri, 2008) and were adjusted to reflect the instructor perspective. In addition, the survey conducted by the Evaluation Department of the Open University of Israel in June 2007 (Alberton, 2007) has provided important insights regarding the tutors' attitudes toward the assignments system, such as the tutors' concern for the students' needs (see H10 discussed in the previous section). Since the population of course coordinators is not large, five course coordinators, who instruct diverse knowledge areas, were asked to answer the pilot version of the questionnaire and comment on it. Following the analysis of their feedback, the questionnaire was slightly refined.

The final questionnaire was sent by e-mail to all the 275 course coordinators of the Open University in July 2008. 69 respondents answered the questionnaire within a week and an additional 27 responded after reminders, resulting in a total of 96 responses, which is an overall $34.9 \%$ effective response rate (the unusable partial responses were excluded from the analysis). Non-response bias was measured by comparing the early respondents and the late respondents, who answered after the reminding email (Armstrong \& Overton, 1977). There were no significant differences between the two groups. 89 respondents served also as tutors and their responses were analyzed in this study.

\section{Results}

Demographic characteristics of the 89 tutors who answered the survey are presented in Table 1, and they are similar to those of the population. There were no age or gender differences in the model, and this is noteworthy due to the wide age range of the participants: $43 \%$ of them were between 40 to 49 years old, $32 \%$ were $50-59$ years old, and $23 \%$ were $30-39$ years old. Term, which is the number of semesters that the tutor has been using the assignments system, was posi- 
tively related to social influence, and those tutors who have been using the system longer, were less inclined to prefer reading from a hard copy to reading from a computer screen.

\begin{tabular}{|l|c|c|c|c|}
\hline \multicolumn{5}{|c|}{ Table 1. Demographic characteristics of survey participants } \\
\hline \multirow{2}{*}{ Gender } & Men & Women & \multicolumn{1}{|c|}{} \\
\cline { 2 - 5 } & $33.3 \%$ & $66.7 \%$ & $\mathbf{5 0 - 5 9}$ & Over 60 \\
\hline \multirow{2}{*}{ Age } & $\mathbf{3 0 - 3 9}$ & $\mathbf{4 0 - 4 9}$ & $32 \%$ & $2 \%$ \\
\cline { 2 - 5 } & $23 \%$ & $43 \%$ & & \\
\hline
\end{tabular}

Data analysis was performed with Partial Least Squares (PLS) (Chin, 1998; Chin, Marcolin, \& Newsted, 2003), using smartPLS 2.0 (beta) software (Ringle, Wende, \& Will, 2005). PLS analyzes how the items load on their constructs simultaneously with estimating all the paths in the model and is widely used in Management Information Systems research (Gefen \& Straub, 2005). The instrument items are presented in Appendix 1. A PLS confirmatory factor analysis, presented in Appendix 2, confirmed that all items loaded well on their respective factors, and all the construct loadings were much higher than the cross loadings. Appendix 3 details the mean, standard deviation, and PLS reliability of the constructs, as well as the correlation among the constructs and their square root of the average variance extracted (AVE). All these measures are above the limit values suggested in the literature (Gefen, Straub, \& Boudreau, 2000). Hence, the findings support adequate convergent and discriminant validity of the constructs.

Figure 2 presents the standardized PLS path coefficients model. The coefficients are shown next to the arrows, and are significant at least at the .05 level. The R-squared values are presented inside the box of the relevant constructs. All the other paths were insignificant. Behavioral intention of the tutors to use the assignment system was significantly influenced directly by its compatibility with the assignment checking process $(\mathrm{H} 7)$, its perceived usefulness (H3), its real value (H2),

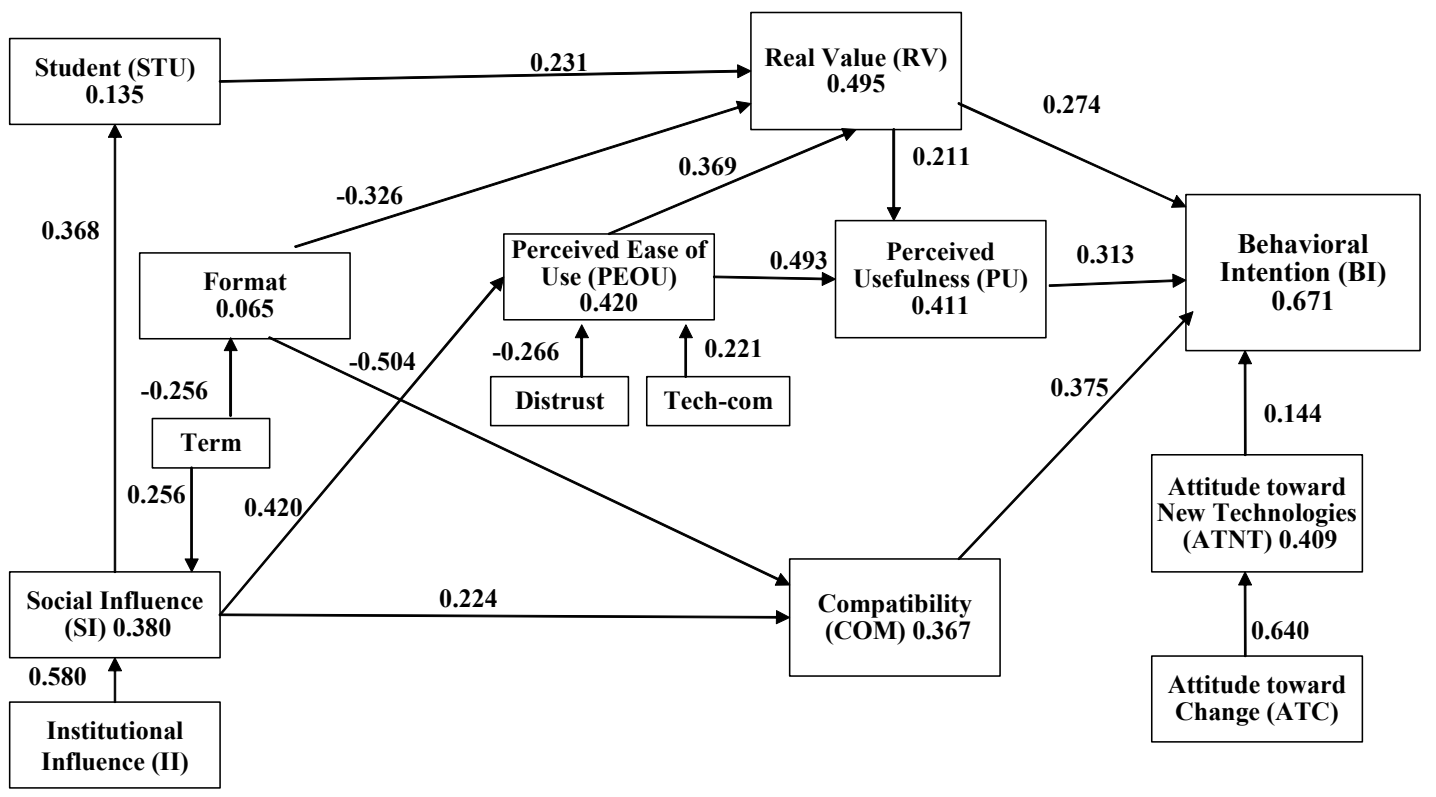

Figure 2: PLS Results for the Proposed Research Model 
and tutors' attitude toward new technologies (H13). There was no direct influence of perceived ease of use (H4), social influence (H8), institutional influence (H9), and students' utility (H10) on behavioral intention. However, all these constructs had an indirect positive influence on behavioral intention, as shown in Figure 2. Hypotheses H1, H5, H6, H11, H12, H14 and H15 were all supported.

\section{Discussion}

\section{Discussion of the Findings and Theoretical Implications}

This study examined the reasons for the slow adoption rate of an apparently simple assignments system. The relatively high R-squared value (0.671) of the behavioral intention construct suggests that the research model can provide explanation for this phenomenon. The current study findings are in accord with prior studies of the assignments systems (Geri \& Naor-Elaiza, 2008; NaorElaiza \& Geri, 2008), which concerned the students, in two main aspects: Behavioral intention to use the system was affected by its perceived usefulness and the potential users' attitude toward change, and PEOU positively influenced PU.

However, unlike the student surveys, which dealt with non-users and former users, PEOU did not affect behavioral intention of the tutors directly. The average value of this construct was quite high (6.03), but it seems that compatibility, PU, and real value of the system had the main influence on tutors' behavior. This discrepancy is expected since there is a difference between initial use of an innovation and intentions to continue using it in the future by those who have already tried it (Agarwal \& Prasad, 1997).

Also, based on the comments of the prior studies participants (Alberton, 2007; Geri \& NaorElaiza, 2008; Naor-Elaiza \& Geri, 2008), this study added the issue of format preference to the model. The findings suggest that reluctance to use the system may also be related to tutors' preference for reading from paper rather than a screen. Few tutors prefer to download the assignments, print them, read the printed version, and then add their comments to the digital version and return the assignments to the students via the system. Since this process is cumbersome, such tutors may be reluctant to use the system.

\section{Practical Implications}

The main practical implications of this study are that the system is not compatible with the checking process of those tutors that are reluctant to use it. Therefore, the system and work processes should become more compatible with the various tutors needs in order to enhance its use. Furthermore, Institutional influence was quite high (6.11, SD 1.02), as well as the perceived ease of use (6.03, SD 1.05), but both did not affect behavioral intention directly. This emphasizes the importance of the compatibility aspect.

Integration of these findings with those of the students' surveys (Geri \& Naor-Elaiza, 2008; NaorElaiza \& Geri, 2008), which suggest that the students may not have been sufficiently encouraged to use the assignments system, implies that compatibility with the tutors needs is the critical issue. Although some technical improvements of the system may enhance its use, there are still individual factors, such as preferred reading format, which may reduce its adoption rate.

\section{Limitations and Further Research}

The main limitation of this study is that it concerned one system and it has been conducted at one university. Hence, replication in more varied settings, including other e-learning and business systems, is required in order to generalize its findings. While the instructional context may be different from systems that are used within an organization, the findings may be relevant to sys- 
tems that are aimed at customers. These findings may provide a basis for further studies concerning continued use of such systems, especially Web-based systems.

This paper is part of a comprehensive study of the assignments system, which investigated the reasons for its slow adoption rate. It examined this issue from the tutors' perspective. Two previous papers focused on the students, one dealt with those students that have never used the system (Naor-Elaiza \& Geri, 2008), and the other paper analyzed former users that apparently abandoned the system (Geri \& Naor-Elaiza, 2008). Some possible explanations for the slow adoption were suggested in the Discussion Section of this paper. The next steps involve reporting on findings concerning other stakeholders, as well as an integrated analysis of all the findings.

\section{Conclusion}

Continued use of a system beyond initial adoption is one of the most challenging issues in practice and research. This study examined the continued use of an online assignment submission system that was implemented in a blended distance learning university. The paper analyzed the system's continued use from the tutor's perspective. Although the system seems very similar to email and is easy to use, its adoption rate is slow. After nine years of implementation, about half of the assignments were submitted via the system. The research model, which is based mainly on the technology acceptance model and diffusion of innovation theory, has been empirically examined with data collected via a Web survey from 89 tutors.

Behavioral intention to use the system was influenced mainly by its compatibility with the assignment checking process, its perceived usefulness, its real value, and tutors' attitude toward new technologies. The findings suggest that the system is not compatible with the checking process of those tutors who are reluctant to use it, and it may be related to their preference for reading from paper rather than a screen. This final element is apparently beyond the control of the organization. Nevertheless, as new innovative applications such as Amazon Kindle, which is a software and hardware platform for reading electronic books, evolve, digital reading may become more

comfortable. Nevertheless, adjusting the system so it will better support the assaginment checking process is the key for increasing its rate of adoption.

\section{Acknowledgements}

The authors are grateful to Yael Alberton and Dr. Relly Brickner of the Evaluation Department, The Open University of Israel, for sharing the data of the tutors' survey that was conducted in June 2007. Special thanks to the course coordinators and tutors who contributed to this study.

\section{References}

Agarwal, R., \& Prasad, J. (1997). The role of innovation characteristics and perceived voluntariness in the acceptance of information technologies. Decision Sciences, 28(3), 557-582.

Ahituv, N. (1989). Assessing the value of information: Problems and approaches. Proceedings of the 10th Annual International Conference on Information Systems, Boston, MA (December 1989): 315-325.

Ajzen I. \& Fishbein, M. (1980). Understanding attitudes and predicting social behavior. Englewood Cliffs, NJ: Prentice Hall.

Alberton, Y. (2007). The online assignments submission system: A survey of tutors who have been using the system. Internal report, the Evaluation department, The Open University of Israel (Hebrew).

Armstrong, J. S., \& Overton, T. S. (1977). Estimating nonresponse bias in mail surveys. Journal of Marketing Research, 14(August), 396-402. 
Not as Easy as E-Mail: Tutors' Perspective of an Online Assignment Submission System

Barnes, S. J., \& Huff S. L. (2003). Rising sun: iMode and the wireless internet. Communications of the $A C M, 46(11), 78-84$.

Bhattacherjee, A. (2001). Understanding information systems continuance: An expectation-confirmation model. MIS Quarterly, 25(3), 351-370.

Bhattacherjee, A., \& Premkumar, G. (2004). Understanding changes in belief and attitude toward information technology usage: A theoretical model and longitudinal test. MIS Quarterly, 28(2), 229-254.

Buzzetto-More, N. A. (2008). Student perceptions of various e-learning components. Interdisciplinary Journal of E-Learning and Learning Objects, 4, 113-135. Retrieved July 30, 2009 from http://ijklo.org/Volume4/IJELLOv4p113-135Buzzetto413.pdf

Buzzetto-More, N. A., Sweat-Guy, R., \& Elobaid, M. (2007). Reading in a digital age: e-books are students ready for this learning object?. Interdisciplinary Journal Knowledge and Learning Objects, 3, 239-250. Retrieved July 30, 2009 from http://ijklo.org/Volume3/IJKLOv3p239-250Buzzetto.pdf

Chan, M., \& Waugh, R. (2007). Factors affecting student participation in the online learning environment at the Open University of Hong Kong. The Journal of Distance Education / Revue de l'Éducation à Distance [Online] 21(3), 23-38. Retrieved February 27, 2008 from http://www.jofde.ca/index.php/jde/article/view/31

Chin, W. W. (1998). Issues and opinions on structural equation modeling. MIS Quarterly 22(1), 7-16.

Chin, W. W., Marcolin, B. L., \& Newsted, P. R. (2003). A partial least squares latent variable modeling approach for measuring interaction effects: Results from a Monte Carlo simulation study and an electronic mail adoption study. Information Systems Research, 14(2), 189-217.

Davis, F. D. (1989). Perceived usefulness, perceived ease of use, and user acceptance of information technology. MIS Quarterly, 13(3), 318-340.

Davis, F. D., Bagozzi, R. P., \& Warshaw, P. R. (1989). User acceptance of computer technology: A comparison of two theoretical models. Management Science, 35(8), 982-1004.

Delone, W. H., \& Mclean, E. R. (1992). Information systems success: The quest for the dependent variable. Information Systems Research, 3(1), 60-95.

Delone, W. H., \& Mclean, E. R. (2003). The DeLone and McLean model of information systems success: A ten-year update. Journal of Management Information Systems, 19(4), 9-30.

Eshet-Alkalai, Y., \& Geri, N. (2007). Does the medium affect the message? The influence of text representation format on critical thinking. Human Systems Management, 26(4), 269-279.

Eshet-Alkalai, Y., \& Geri, N. (2009). Congruent versus incongruent display: The effect of page layout on critical reading in print and digital formats. In Y. Eshet-Alkalai, A. Caspi, S. Eden, N. Geri, \& Y. Yair (Eds.), Learning in the Technological Era: Proceedings of the Chais Conference on Instructional Technologies research (pp. 73-80). Ra'anana, Israel: The Open University of Israel. Retrieved May 8, 2009 from http://telem-pub.openu.ac.il/users/chais/2009/noon/3 2.pdf

Gefen, D. (2003). TAM or just plain habit: A look at experienced online shoppers. Journal of End User Computing, 15(3), 1-13.

Gefen, D., Karahanna, E. \& Straub, D. W. (2003). Trust and TAM in online shopping: An integrated model. MIS Quarterly, 27(1), 51-90.

Gefen, D., \& Straub, D. W. (2005). A practical guide to factorial validity using PLS-Graph: Tutorial and annotated example. Communications of the AIS, 16(5), 91-109.

Gefen, D., Straub, D. W., \& Boudreau, M. C. (2000). Structural equation modeling and regression: Guidelines for research practice. Communications of the AIS, 4(7), 1-78. Retrieved February 27, 2008 from http://www.cis.gsu.edu/ dstraub/Papers/Resume/Gefenetal2000.pdf 
Geri, N., \& Naor-Elaiza, O. (2008). Beyond adoption: Barriers to an online assignment submission system continued use. Interdisciplinary Journal of E-Learning and Learning Objects, 4, 225-241. Retrieved October 26, 2008 from http://ijello.org/Volume4/IJELLOv4p225-241Ger476.pdf

Jeyaraj, A., Rottman, J. W., \& Lacity, M. C. (2006). A review of the predictors, linkages, and biases in IT innovation adoption research. Journal of Information Technology, 21(1), 1-23.

Karahanna, E., Agarwal, R., \& Angst, C. M. (2006). Reconceptualizing compatibility beliefs in technology acceptance research. MIS Quarterly, 30(4), 781-804.

Karahanna, E., Straub, D. W. \& Chervany, N. L. (1999). Information technology adoption across time: A cross-sectional comparison of pre-adoption and post-adoption beliefs. MIS Quarterly, 23(2), 183-213.

Kim, S. S., \& Malhotra, N. K. (2005). A Longitudinal model of continued IS use: An integrative view of four mechanisms underlying post-adoption phenomena. Management Science, 51(5), 741-755.

Koohang, A. (2004). Expanding the concept of usability. Informing Science: the International Journal of an Emerging Transdiscipline, 7, 129-141. Retrieved from http://inform.nu/Articles/Vol7/v7p129-141002.pdf

Langley, D., Ronen, M., \& Ben Shachar, S. (2008). Open online assignment submission: First year students' behavior and views. Issues in Informing Science and Information Technology, 5, 297-310. Retrieved July 30, 2009 from http://proceedings.informingscience.org/InSITE2008/IISITv5p297310Langley512.pdf

Levy, Y. (2006). The top 10 most valuable online learning activities for graduate MIS students. International Journal of Information and Communication Technology Education, 2(3), 27-44.

Moore, G. C., \& Benbasat, I. (1991). Development of an instrument to measure the perceptions of adopting an information technology innovation. Information Systems Research, 2(3), 192-222.

Naor-Elaiza, O., \& Geri, N. (2008). Easy as e-Mail? Probing the Slow Adoption of an Online Assignment Submission System. In Y. Eshet-Alkalai, A. Caspi, \& N. Geri (Eds.), Learning in the Technological Era: Proceedings of the Chais Conference on Instructional Technologies research (pp. 94-101). Ra'anana, Israel: The Open University of Israel. Retrieved February 27, 2008 from http://telem-pub.openu.ac.il/users/chais/2008/morning/1_2.pdf

Pavlou, P.A., \& Gefen, D. (2004). Building effective online marketplaces with institution-based trust. Information Systems Research, 15(1), 37-59.

Petter, S., Delone, W., \& Mclean, E. (2008). Measuring information systems success: Models, dimensions, measures, and interrelationships. European Journal of Information Systems, 17(3), 236-263.

Raban, D. R, (2007). User-centered evaluation of information: A research challenge. Internet Research, 17(3), 306-322.

Ringle, C. M., Wende, S., \& Will, A. (2005). SmartPLS 2.0 (beta). http://www.smartpls.de.

Rogers, E. M. (1962). Diffusion of innovation. New-York: The Free Press.

Rogers, E. M. (2003). Diffusion of innovation (5th ed.). New-York: The Free Press.

Spencer, C. (2006). Research on learners' preferences for reading from a printed text or from a computer screen. The Journal of Distance Education / Revue de l'Éducation à Distance [Online] 21(1), 33-50. Retrieved February 27, 2008 from http://www.jofde.ca/index.php/jde/article/view/70/51.

Venkatesh, V., Morris, G. M., Davis, G. B., \& Davis, F. D. (2003). User acceptance of information technology: Toward a unified view. MIS Quarterly, 27(3), 425-478. 


\section{Appendix 1. Instrument Items}

\begin{tabular}{|c|c|c|c|}
\hline Construct & Code & Items & Loading \\
\hline \multirow{2}{*}{$\begin{array}{l}\text { Attitude } \\
\text { toward } \\
\text { Change }\end{array}$} & ATC1 & It is easy for me to get used to new procedures. & 0.921 \\
\hline & ATC2 & It is easy for me to cope with changes. & 0.920 \\
\hline \multirow{2}{*}{$\begin{array}{l}\text { Attitude } \\
\text { toward New } \\
\text { Technologies }\end{array}$} & ATNT1 & It is important for me to use advanced technologies. & 0.939 \\
\hline & ATNT2 & I am interested in innovative gadgets. & 0.840 \\
\hline \multirow[t]{3}{*}{$\begin{array}{l}\text { Behavioral } \\
\text { Intention }\end{array}$} & BI1 & $\begin{array}{l}\text { I hope that in the future the students will be required to use the } \\
\text { assignments system. }\end{array}$ & 0.876 \\
\hline & BI2 & $\begin{array}{l}\text { I encourage the students in my groups to use the assignments } \\
\text { system. }\end{array}$ & 0.913 \\
\hline & $\mathrm{BI} 3$ & $\begin{array}{l}\text { In most cases, I would prefer to evaluate assignments that were } \\
\text { submitted via the assignments system. }\end{array}$ & 0.942 \\
\hline \multirow[t]{3}{*}{ Compatibility } & COM1Inv & In most cases, it is easier for me to handwrite my comments. & 0.844 \\
\hline & COM2Inv & $\begin{array}{l}\text { In my courses, it is harder to submit and check assignments via } \\
\text { the assignments system because they include graphs or mathe- } \\
\text { matical formulas. }\end{array}$ & 0.778 \\
\hline & COM3Inv & $\begin{array}{l}\text { The nature of the assignments in my courses is not compatible } \\
\text { with the assignments system. }\end{array}$ & 0.837 \\
\hline \multirow[t]{3}{*}{ DisTrust } & DisTrust1 & $\begin{array}{l}\text { I am afraid that the assignments system is not completely reli- } \\
\text { able. }\end{array}$ & 0.896 \\
\hline & DisTrust2 & $\begin{array}{l}\text { I hesitate to use the system for fear of making mistakes it will } \\
\text { be hard for me to correct. }\end{array}$ & 0.836 \\
\hline & DisTrust3 & $\begin{array}{l}\text { It scares me to think that I could lose information by hitting the } \\
\text { wrong key. }\end{array}$ & 0.781 \\
\hline \multirow[t]{2}{*}{ Format } & Format1 & $\begin{array}{l}\text { I prefer to evaluate hard-copy printed materials rather than } \\
\text { using a computer. }\end{array}$ & 0.945 \\
\hline & Format2 & $\begin{array}{l}\text { Reading assignments from a computer screen for a long time is } \\
\text { hard for me. }\end{array}$ & 0.889 \\
\hline \multirow{2}{*}{$\begin{array}{l}\text { Institutional } \\
\text { Influence }\end{array}$} & III & My supervisors expect me to use the assignments system. & 0.918 \\
\hline & II 2 & The university management encourages use of the system. & 0.903 \\
\hline \multirow{2}{*}{$\begin{array}{l}\text { Perceived } \\
\text { Ease of Use }\end{array}$} & PEOU1 & Generally, in my opinion the system is easy to use. & 0.957 \\
\hline & PEOU2 & The assignments system is user-friendly. & 0.958 \\
\hline \multirow{3}{*}{$\begin{array}{l}\text { Perceived } \\
\text { Usefulness }\end{array}$} & PU1 & It is more convenient to handle appeals via the system. & 0.736 \\
\hline & PU2 & $\begin{array}{l}\text { Using the system saves dealing with inquiries whether assign- } \\
\text { ments were received, were lost, or were graded and returned. }\end{array}$ & 0.763 \\
\hline & PU3 & $\begin{array}{l}\text { Using the system decreases the time and hassle involved with } \\
\text { administrative aspects of receiving and returning assignments. }\end{array}$ & 0.861 \\
\hline \multirow[t]{2}{*}{ Real Value } & RV1 & $\begin{array}{l}\text { Using the system enhances the efficiency of the checking proc- } \\
\text { ess because sometimes it enables reuse of comments. }\end{array}$ & 0.899 \\
\hline & RV2 & $\begin{array}{l}\text { Generally, the quality of the feedback I provided on assign- } \\
\text { ments that were submitted through the system was better. }\end{array}$ & 0.859 \\
\hline \multirow{3}{*}{$\begin{array}{l}\text { Social } \\
\text { Influence/ } \\
\text { Observability }\end{array}$} & SI1 & My fellow course coordinators use the system a lot. & 0.856 \\
\hline & SI2 & $\begin{array}{l}\text { People in my department think that the use of the assignments } \\
\text { system should be encouraged. }\end{array}$ & 0.842 \\
\hline & SI3 & My fellow course coordinators are satisfied with the system. & 0.806 \\
\hline \multirow[t]{3}{*}{ Students } & STU1 & $\begin{array}{l}\text { In my opinion, the assignments system helps students by ena- } \\
\text { bling them to get faster feedback on the assignments. }\end{array}$ & 0.822 \\
\hline & STU2 & $\begin{array}{l}\text { In my opinion, the assignments system helps students by orga- } \\
\text { nizing the assignments and improving the learning process. }\end{array}$ & 0.824 \\
\hline & STU3 & $\begin{array}{l}\text { In my opinion, the system helps students by enabling them to } \\
\text { get feedback on all the assignments before the exams. }\end{array}$ & 0.857 \\
\hline \multirow[t]{2}{*}{$\begin{array}{l}\text { Technical } \\
\text { Compatibility }\end{array}$} & Tech-com 1 Inv & $\begin{array}{l}\text { Downloading the assignments to my own computer is incon- } \\
\text { venient because it prevents me from checking the assignments } \\
\text { through other computers. }\end{array}$ & 0.713 \\
\hline & Tech-com2Inv & $\begin{array}{l}\text { In my opinion, the technical aspects of downloading and up- } \\
\text { loading assignments are cumbersome. }\end{array}$ & 0.943 \\
\hline
\end{tabular}


Appendix 2. Confirmatory Factor Analysis in PLS

\begin{tabular}{|c|c|c|c|c|c|c|c|c|c|c|c|c|c|c|}
\hline & $\frac{B}{\Omega}$ & $\underset{B}{\stackrel{B}{Z}}$ & 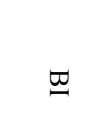 & $\stackrel{8}{3}$ & 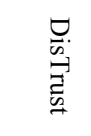 & 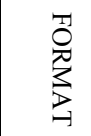 & $=$ & $\stackrel{\vec{T}}{\stackrel{T}{0}}$ & $\widetilde{c}$ & ల & $\mathscr{\Omega}$ & $\stackrel{\sim}{\mathcal{C}}$ & 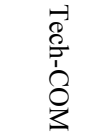 & $\frac{ت}{\pi}$ \\
\hline ATC1 & 0.921 & 0.591 & 0.292 & 0.233 & -0.467 & -0.195 & 0.015 & 0.279 & 0.445 & 0.313 & 0.189 & 0.307 & 0.176 & 0.255 \\
\hline ATC2 & 0.920 & 0.586 & 0.257 & 0.053 & -0.425 & -0.083 & 0.023 & 0.121 & 0.373 & 0.248 & 0.152 & 0.221 & 0.099 & 0.199 \\
\hline ATNT1 & 0.633 & 0.939 & 0.466 & 0.240 & -0.332 & -0.191 & -0.028 & 0.129 & 0.298 & 0.408 & 0.116 & 0.247 & 0.083 & 0.276 \\
\hline ATNT2 & 0.486 & 0.840 & 0.157 & -0.009 & -0.204 & -0.081 & 0.021 & 0.034 & 0.185 & 0.137 & 0.037 & 0.139 & 0.060 & 0.281 \\
\hline BI1 & 0.202 & 0.272 & 0.913 & 0.603 & -0.192 & -0.494 & 0.020 & 0.521 & 0.488 & 0.589 & 0.402 & 0.381 & 0.314 & 0.305 \\
\hline BI2 & 0.366 & 0.436 & 0.876 & 0.490 & -0.207 & -0.522 & -0.007 & 0.462 & 0.538 & 0.588 & 0.352 & 0.354 & 0.150 & 0.229 \\
\hline BI3 & 0.252 & 0.344 & 0.942 & 0.647 & -0.313 & -0.612 & 0.043 & 0.613 & 0.638 & 0.657 & 0.433 & 0.442 & 0.368 & 0.251 \\
\hline COM1 & 0.147 & 0.102 & 0.478 & 0.778 & -0.246 & -0.263 & 0.196 & 0.336 & 0.139 & 0.293 & 0.325 & 0.207 & 0.233 & 0.055 \\
\hline COM2 & 0.206 & 0.197 & 0.456 & 0.837 & -0.327 & -0.363 & 0.085 & 0.300 & 0.300 & 0.311 & 0.280 & 0.359 & 0.230 & 0.148 \\
\hline COM3 & 0.062 & 0.106 & 0.607 & 0.844 & -0.252 & -0.668 & 0.111 & 0.415 & 0.326 & 0.584 & 0.297 & 0.392 & 0.305 & 0.266 \\
\hline DisTrust1 & -0.361 & -0.249 & -0.244 & -0.332 & 0.896 & 0.246 & -0.194 & -0.435 & -0.320 & -0.280 & -0.181 & -0.134 & -0.366 & -0.171 \\
\hline DisTrust2 & -0.441 & -0.282 & -0.228 & -0.290 & 0.836 & 0.204 & -0.082 & -0.379 & -0.410 & -0.252 & -0.072 & -0.325 & -0.415 & -0.117 \\
\hline DisTrust3 & -0.471 & -0.276 & -0.178 & -0.157 & 0.781 & 0.139 & -0.154 & -0.203 & -0.242 & -0.183 & -0.095 & -0.065 & -0.480 & -0.214 \\
\hline FORMAT1 & -0.155 & -0.229 & -0.654 & -0.534 & 0.213 & 0.945 & -0.088 & -0.335 & -0.388 & -0.545 & -0.299 & -0.211 & -0.328 & -0.329 \\
\hline FORMAT2 & -0.118 & -0.043 & -0.408 & -0.505 & 0.245 & 0.889 & -0.013 & -0.176 & -0.338 & -0.314 & -0.197 & -0.220 & -0.219 & -0.106 \\
\hline III & 0.047 & 0.002 & 0.108 & 0.180 & -0.171 & -0.097 & 0.918 & 0.310 & 0.063 & 0.126 & 0.531 & 0.110 & 0.060 & -0.083 \\
\hline II 2 & -0.011 & -0.020 & -0.076 & 0.098 & -0.136 & -0.011 & 0.903 & 0.152 & -0.163 & 0.027 & 0.490 & 0.054 & -0.018 & -0.053 \\
\hline PEOU1 & 0.240 & 0.113 & 0.528 & 0.408 & -0.447 & -0.227 & 0.219 & 0.957 & 0.615 & 0.527 & 0.453 & 0.536 & 0.434 & 0.240 \\
\hline PEOU2 & 0.177 & 0.084 & 0.597 & 0.428 & -0.381 & -0.332 & 0.274 & 0.958 & 0.569 & 0.604 & 0.506 & 0.518 & 0.385 & 0.073 \\
\hline PU1 & 0.302 & 0.042 & 0.355 & 0.175 & -0.163 & -0.170 & -0.198 & 0.401 & 0.736 & 0.299 & 0.068 & 0.444 & 0.314 & 0.065 \\
\hline PU2 & 0.484 & 0.338 & 0.569 & 0.310 & -0.446 & -0.383 & 0.058 & 0.549 & 0.861 & 0.425 & 0.311 & 0.376 & 0.416 & 0.340 \\
\hline PU3 & 0.283 & 0.251 & 0.532 & 0.280 & -0.313 & -0.375 & -0.034 & 0.534 & 0.831 & 0.475 & 0.260 & 0.399 & 0.267 & 0.202 \\
\hline RV1 & 0.340 & 0.320 & 0.618 & 0.468 & -0.295 & -0.381 & 0.086 & 0.632 & 0.459 & 0.899 & 0.348 & 0.551 & 0.295 & 0.133 \\
\hline RV2 & 0.184 & 0.267 & 0.561 & 0.435 & -0.217 & -0.485 & 0.063 & 0.391 & 0.423 & 0.859 & 0.245 & 0.330 & 0.205 & 0.122 \\
\hline SI1 & 0.239 & 0.129 & 0.319 & 0.235 & -0.032 & -0.124 & 0.376 & 0.402 & 0.248 & 0.314 & 0.856 & 0.335 & 0.111 & 0.139 \\
\hline SI2 & 0.169 & 0.094 & 0.355 & 0.333 & -0.113 & -0.217 & 0.641 & 0.360 & 0.172 & 0.285 & 0.842 & 0.314 & 0.074 & 0.192 \\
\hline $\mathrm{SI} 3$ & 0.061 & 0.018 & 0.415 & 0.335 & -0.212 & -0.350 & 0.354 & 0.500 & 0.296 & 0.259 & 0.806 & 0.273 & 0.299 & 0.195 \\
\hline STU1 & 0.230 & 0.167 & 0.361 & 0.418 & -0.329 & -0.241 & 0.081 & 0.475 & 0.346 & 0.430 & 0.220 & 0.822 & 0.305 & 0.044 \\
\hline STU2 & 0.237 & 0.221 & 0.417 & 0.318 & -0.070 & -0.207 & 0.101 & 0.464 & 0.472 & 0.397 & 0.375 & 0.824 & 0.180 & -0.014 \\
\hline STU3 & 0.250 & 0.179 & 0.308 & 0.280 & -0.181 & -0.142 & 0.047 & 0.443 & 0.406 & 0.450 & 0.316 & 0.857 & 0.228 & 0.008 \\
\hline Tech-COM1 & -0.057 & -0.005 & 0.170 & 0.094 & -0.255 & -0.217 & -0.087 & 0.212 & 0.184 & 0.103 & 0.108 & 0.088 & 0.713 & 0.266 \\
\hline Tech-COM2 & 0.219 & 0.107 & 0.315 & 0.365 & -0.492 & -0.291 & 0.074 & 0.447 & 0.438 & 0.320 & 0.192 & 0.319 & 0.943 & 0.183 \\
\hline TERM & 0.247 & 0.309 & 0.286 & 0.210 & -0.188 & -0.256 & -0.075 & 0.163 & 0.268 & 0.145 & 0.212 & 0.014 & 0.241 & 1.000 \\
\hline
\end{tabular}




\section{Appendix 3. Correlation Matrix, Descriptives and Average Variance Extracted of Principal Components}

Mean, Standard Deviation, and PLS reliability together with the correlation among the constructs and their square root of the AVE. Correlations of latent variables and Square Root of the AVE are presented in the diagonals.

\begin{tabular}{|c|c|c|c|c|c|c|c|c|c|c|c|c|c|c|c|c|c|}
\hline & 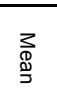 & 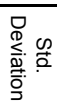 & 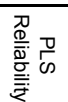 & 긍 & $\sum_{-1}^{2}$ & $\underline{\square}$ & గి & 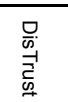 & 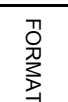 & $=$ & 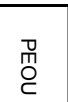 & D & $\prod^{\pi}$ & $\underline{\omega}$ & $\stackrel{\mathcal{O}}{\subset}$ & 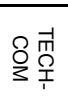 & 㧫 \\
\hline ATC & 5.54 & 1.23 & 0.92 & 0.920 & 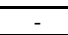 & - & - & - & - & - & - & - & - & - & - & - & - \\
\hline ATNT & 5.21 & 1.28 & 0.88 & 0.640 & 0.890 & - & - & - & - & - & - & - & - & - & - & - & - \\
\hline $\mathrm{Bl}$ & 5.42 & 1.64 & 0.94 & 0.298 & 0.384 & 0.911 & - & - & - & - & - & - & - & - & - & - & - \\
\hline $\mathrm{COM}$ & 5.05 & 1.81 & 0.86 & 0.155 & 0.159 & 0.640 & 0.820 & - & - & - & - & - & - & - & - & - & - \\
\hline \begin{tabular}{|l|} 
DisTrust \\
\end{tabular} & 2.15 & 1.07 & 0.88 & -0.485 & -0.313 & -0.264 & -0.331 & 0.839 & - & - & - & - & - & - & - & - & - \\
\hline \begin{tabular}{|l|} 
FORMAT \\
\end{tabular} & 3.63 & 1.89 & 0.91 & -0.151 & -0.165 & -0.598 & -0.566 & 0.246 & 0.917 & - & - & - & - & - & - & - & - \\
\hline II & 6.11 & 1.02 & 0.91 & 0.021 & -0.010 & 0.022 & 0.155 & -0.169 & -0.061 & 0.911 & - & - & - & - & - & - & - \\
\hline PEOU & 6.03 & 1.05 & 0.96 & 0.218 & 0.103 & 0.588 & 0.437 & -0.432 & -0.292 & 0.257 & 0.957 & - & - & - & - & - & - \\
\hline $\mathrm{PU}$ & 5.90 & 1.14 & 0.85 & 0.445 & 0.282 & 0.612 & 0.323 & -0.397 & -0.398 & -0.050 & 0.618 & 0.811 & - & - & - & - & - \\
\hline $\mathrm{RV}$ & 4.53 & 1.83 & 0.87 & 0.305 & 0.336 & 0.672 & 0.514 & -0.294 & -0.487 & 0.086 & 0.591 & 0.503 & 0.879 & - & - & - & - \\
\hline $\mathrm{SI}$ & 5.27 & 1.07 & 0.87 & 0.185 & 0.095 & 0.436 & 0.365 & -0.145 & -0.278 & 0.561 & 0.501 & 0.282 & 0.342 & 0.835 & - & - & - \\
\hline STU & 5.52 & 1.13 & 0.87 & 0.287 & 0.227 & 0.4033 & 0.402 & -0.225 & -0.233 & 0.091 & 0.551 & 0.491 & 0.510 & 0.368 & 0.834 & & - \\
\hline TECH-COM & 4.78 & 1.57 & 0.82 & 0.150 & 0.082 & 0.309 & 0.319 & -0.478 & -0.307 & 0.025 & 0.428 & 0.410 & 0.288 & 0.190 & 0.281 & 0.836 & \\
\hline \begin{tabular}{|c|} 
TERM \\
\end{tabular} & 3.62 & 0.90 & single & 0.247 & 0.309 & 0.286 & 0.210 & -0.188 & -0.256 & -0.075 & 0.163 & 0.268 & 0.145 & 0.212 & 0.014 & 0.241 & 1.000 \\
\hline
\end{tabular}

\section{Biographies}

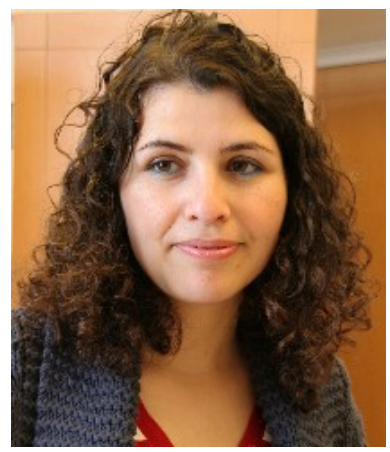

Orit Naor-Elaiza is Head of the sub-department of data analysis and processing at the Human Resources Administration of The Open University of Israel, and has over ten years of professional experience. Orit is a member of the Chais Research Center for the Integration of Technology in Education. She holds a B.A. in Management and Computer Science from the Open University of Israel and an MBA from the Graduate School of Business Administration, Bar-Ilan University. Her area of research is technology acceptance. Personal site: http://www.openu.ac.il/research_center_eng/Orit-Naor-Elaiza.html

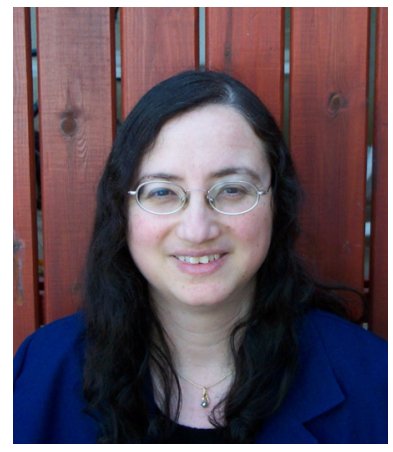

Nitza Geri is Chair of the Department of Management and Economics, the Open University of Israel, and a member of the Chais Research Center for the Integration of Technology in Education. She holds a B.A. in Accounting and Economics, an M.Sc. in Management Sciences and a Ph.D. in Technology and Information Systems Management from Tel-Aviv University. Nitza is a CPA (Israel) and prior to her academic career she had over 12 years of business experience. Her research interests and publications focus on various aspects of the value of information, and information systems adoption and implementation, including strategic information systems, e-business, value creation and the Theory of Constraints, managerial aspects of e-learning systems adoption and use. Personal site: http://www.openu.ac.il/Personal sites/nitza-geri.html. 